OmniAkuatika, 12 (2): 58-66, 2016
ISSN: 1858-3873 print / 2476-9347 online
Research Article

\title{
Profil Oseanografi Biologi Laut Banda: Sebuah Tinjauan Kritis
}

\author{
Yosmina H. Tapilatu ${ }^{1, *}$ \\ Pusat Penelitian Laut Dalam-Lembaga IImu Pengetahuan Indonesia (PPLD-LIPI) \\ Jl. Y. Syaranamual Guru-guru Poka Ambon 97233 \\ *Corresponding auhor : yosmina.tapilatu@lipi.go.id
}

Received 10 June 2016; Accepted 10 October 2016; Available online 29 November 2016

\begin{abstract}
Informasi mengenai keragaan oseanografi biologi di Laut Banda sangat penting dalam rangka menunjang pembangunan kelautan dan perikanan di perairan yang kaya dengan sumber daya alam ini, baik hayati maupun nir hayati. Makalah ini menyajikan tinjauan mengenai kajian oseanografi biologi Laut Banda sejak tahun 1970-an sampai dengan 2013, sebagai upaya untuk mengungkap karakteristik perairan ini, beserta perspektif penggunaannya dalam mendukung pembangunan kelautan dan perikanan di Laut Banda yang beriorientasi kepada pemanfaatan yang berkesinambungan.
\end{abstract}

Keywords: oseanografi biologi, perikanan, kelautan, Laut Banda

\section{Pendahuluan}

Informasi mengenai keragaan oseanografi biologi suatu wilayah perairan laut sangat diperlukan guna menyusun strategi pembangunan kelautan dan perikanan yang komprehensif. Untuk itu penyamaan persepsi, pendefinisian istilah dan pembatasan ruang lingkup bahasan merupakan langkah yang mendasar dalam kerangka pikir yang akan dibahas di sini. Oseanografi biologi pada makalah ini mengacu pada bidang kajian mengenai biota laut, terutama mengenai respons biota yang hidup di dalam kolom air terhadap perubahan keadaan hidrografi yang berbeda karena pengaruh musim. Respons biota tersebut dapat dilihat misalnya dalam bentuk komposisi dan aktivitas plankton -termasuk ichtyoplanktondan bakteri, di Laut Banda. Hal ini karena bakteri dan plankton merupakan dua unsur penting dalam produktivitas perairan. Kajian mengenai ichtyoplankton akan memberikan gambaran yang lebih utuh mengenai profil oseanografi biologi Laut Banda, di luar nekton dan makroorganisme lainnya. Adapun pengamatan dan analisa yang dikemukakan dalam makalah ini dibuat berdasarkan kajian-kajian yang sudah dilakukan sejak tahun 1970-an sampai 2013, dan implikasinya terhadap pembangunan kelautan dan perikanan berbasis perairan ini di Provinsi Maluku.

\section{Latar belakang}

Laut Banda (Gambar 1) merupakan perairan berbentuk cekungan (basin) yang memisahkan paparan Sunda di bagian barat dan paparan Sahul di Bagian Timur. Topografi dasar lautnya sangat kompleks dengan bentuk cekungan di bagian barat dan bentuk palung di bagian timur (Suyarso, 1999). Bentuk topografi yang kompleks ini turut menentukan dalam mengendalikan pertukaran massa air. Lewat pemodelan yang dilakukan dari hasil ekspedisi Snellius yang pertama di tahun 1930-an dan kajian yang dilakukan oleh Lembaga IImu Pengetahuan Indonesia pada tahun 1950-an, Wyrtki (1958, 1961) menyimpulkan bahwa perairan ini berfungsi seperti jantung perairan Indonesia. Pada periode bertiupnya angin muson barat, secara lokal disebut sebagai musim barat (Desember-Februari) akan terjadi penurunan masa air yang berlebih (downwelling) akibat masukan air dari Laut Jawa dan Laut Flores, dan sedikitnya massa air yang mengalir ke Samudera Pasifik. Hal ini mengakibatkan naiknya suhu air permukaan, dan menurunnya salinitas serta unsur hara, sehingga berujung pada menurunnya biomassa plankton. 


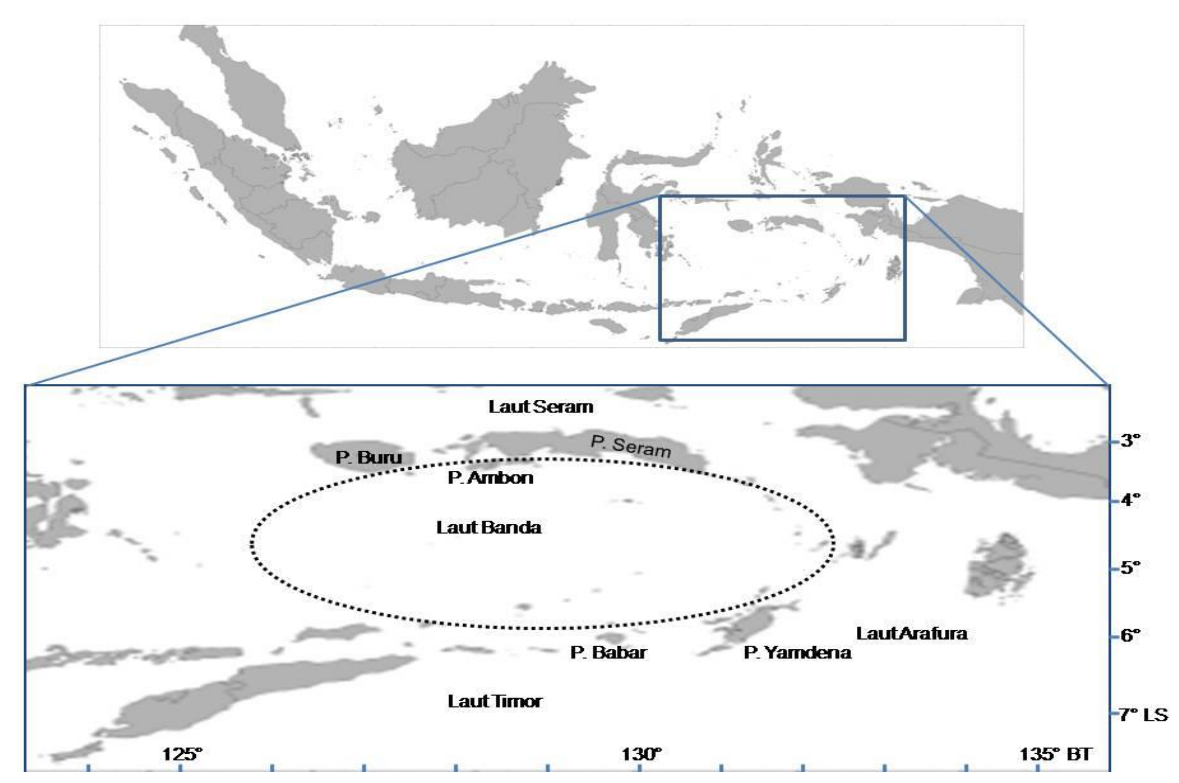

Gambar 1. Peta Indonesia (atas) dan peta Provinsi Maluku (bawah) …... : wilayah geografis Laut Banda.

Sebaliknya pada periode bertiupnya angin muson timur (musim timur), yakni pada bulan Juni hingga Agustus, terjadi pergerakan massa air yang dominan ke arah Laut Flores dan Laut Jawa, sementara massa air yang masuk dari Samudera Pasifik tidak mencukupi. Akibatnya air dari lapisan bawah Laut Banda akan bergerak ke atas, atau dikenal dengan proses pengangkatan massa air (upwelling) (Wyrtki 1958, 1961, Birowo 1984). Sirkulasi ini terkait langsung dengan sirkulasi massa air dunia (ocean conveyor belt) (llahude, 1999). Proses pengangkatan massa air yang terjadi di Laut Banda pada musim timur akibat kekosongan massa air pada lapisan paras mengakibatkan penurunan suhu, naiknya salinitas, dan pengangkatan unsur hara. Tersedianya unsur hara yang berlimpah pada gilirannya akan mempengaruhi kelimpahan plankton, sumber pakan utama ikan-ikan ekonomis penting seperti tuna, cakalang dan tongkol. Namun pengaruh ini bersifat kompleks, seperti yang akan kita lihat dalam bagian hasil dan pembahasan.

\section{Isu-isu strategis}

Pembangunan kelautan dan perikanan berbasis Laut Banda penting artinya bagi Provinsi Maluku, terutama dengan ditetapkannya Provinsi ini sebagai Lumbung Ikan Nasional (LIN). Selain merupakan bagian dari Wilayah Pengelolaan Perikanan Negara Republik Indonesia (WPP-RI) 714, Laut Banda juga termasuk dalam wilayah Inisiatif Segitiga Terumbu Karang, yang dikenal kaya dengan keanekaragaman hayati laut yang tinggi. Pemerintah Republik Indonesia sendiri juga telah menetapkan Laut Banda sebagai Kawasan Konservasi Perairan Nasional berdasarkan Keputusan Menteri Kelautan dan Perikanan Republik Indonesia No. 69/2009. Hal ini karena Laut Banda dikenal memiliki sumber daya alam (hayati dan nirhayati) yang sangat potensial untuk dimanfaatkan.

Data Direktur Jendral Perikanan Tangkap Kementrian Kelautan dan Perikanan pada tahun 2011 menyebutkan bahwa potensi sumber daya ikan pelagis besar di Laut Banda diduga mencapai 104.100 ton per tahun (Besewni dkk, 2011). Karena disinyalir telah terjadi lebih tangkap dan penangkapan yang tidak berbasis pendekatan ekosistem, Laut Banda sendiri telah ditetapkan sebagai bagian dari WPP-RI 714 yang dilarang untuk dijadikan wilayah penangkapan berdasarkan Peraturan Menteri Kelautan dan Perikanan No. 4/PERMEN$\mathrm{KP} / 2015$. Pengelolaannya karena itu harus dilakukan secara bertanggung jawab, sehingga sumber daya alam yang terdapat di Laut Banda dapat digunakan secara berkesinambungan.

Tujuan penulisan makalah ini adalah tersedianya informasi terkini yang menyeluruh dan terpadu mengenai keragaan Oseanografi Biologi Laut Banda berdasarkan kajian yang sudah pernah dilakukan sebelumnya. Hal ini penting untuk memastikan bahwa para 
pemangku kepentingan memperoleh informasi yang akurat dan aktual dalam rangka pembangunan perikanan dan kelautan berbasis perairan tersebut, secara berkelanjutan dan bertanggung jawab.

\section{Metode Pendekatan}

Hasil-hasil kajian mengenai plankton dan produktivitas primer di Laut Banda sejak tahun 1970 sampai dengan 2013 digunakan sebagai sumber primer. Apabila diperlukan informasi lebih lanjut dan/atau ada informasi yang tidak tersedia, pelacakan dilakukan dengan menggunakan mesin pencari umum internet atau situs-situs pengindeks global khusus tulisan ilmiah. Hasil kajian dalam bentuk artikel ilmiah dan/atau laporan penelitian yang tidak tersedia secara elektronik ditelusuri pada perpustakaan Pusat Penelitian Laut Dalam (PPLD) LIPI.

\section{Hasil dan Pembahasan}

Kajian mengenai kondisi perairan Laut Banda sudah dilakukan oleh para peneliti kelautan dari berbagai negara sejak akhir abad ke-19, mulai dari ekspedisi Challenger pada tahun 1872-1876 sampai dengan ekspedisi yang dilakukan oleh para peneliti dari Pusat Penelitian Laut Dalam Lembaga IImu Pengetahuan Indonesia (PPLD-LIPI) pada tahun 2013 yang lalu. Dari kajian-kajian yang dilakukan, diamati bahwa kondisi hidrologi Laut Banda sangat spesifik karena pengaruh musim yang berbeda dalam setahun. Sebagai konsekwensinya, kondisi hidrologi ini juga turut membentuk karakteristik oseanografi biologi Laut Banda.

\section{Kajian tahun 1970 - 1999 fitoplankton}

Hasil kajian Arinardi (1999) mengenai sebaran volume plankton berdasarkan data penelitian yang diperoleh dari tahun $1970 \mathrm{~s} / \mathrm{d}$ 1992 dari masing-masing 70 sampel plankton pada musim barat dan 98 sampel pada musim timur menunjukkan respons hidrologi dari kelompok eukariota ini secara jelas. Sebaran net-fitoplankton relatif padat (lebih dari 1.500 $\mathrm{ml} / 1000 \mathrm{~m}^{3}$ ) dan hanya terlihat pada sekitar $4 \%$ dari area yang diamati pada musim barat, dan terdapat di bagian tenggara Pulau Seram. Sebaliknya pada musim timur seluruh area pengamatan mengandung lebih dari 1.500 $\mathrm{ml} / 1000 \mathrm{~m}^{3}$, dengan kandungan terpadat (lebih dari $2.500 \mathrm{ml} / 1000 \mathrm{~m}^{3}$ ) diamati hanya pada $17 \%$ area pengamatan, terutama di selatan Pulau Ambon-Buru serta di utara Pulau Yamdena (Arinardi, 1999). Lebih lanjut Arinardi mengamati bahwa rata-rata kepadatan volume fitoplankton pada waktu upwelling mencapai $2.463,82$ $\mathrm{ml} / 1.000 \mathrm{~m}^{3}$, atau hampir 2,5 kali lipat ketimbang rata-rata kepadatannya pada musim barat $\left(1.024,88 \mathrm{ml} / 1.000 \mathrm{~m}^{3}\right)$.

Secara spesifik, kelimpahan netfitoplankton di bagian timur Laut Banda pada bulan Agustus (upwelling) ternyata 3 kali lebih banyak daripada pada bulan Februari (downwelling). Struktur komunitas pun didominasi oleh spesies yang berbeda tergantung musim. Pada musim barat Chaetoceros, Bacteriastrum, Coscinodiscus, Thalassiotrix dan Lauderia mendominasi komunitas fitoplankton (Adnan 1990 dan Arinardi dkk. 1997). Sedangkan pada musim timur ditemukan Skeletonema costatum dan Streptotheca sp. (Arinardi 1999).

Hasil pengukuran Adenosin Tri Fosfat (ATP) sebagai jumlah biomassa relatif mikroorganisme berukuran lebih kecil dari $50 \mu \mathrm{m}$ di bagian timur Laut Banda justru tidak dipengaruhi oleh musim. Jika pada bulan Agustus (upwelling) nilainya mencapai $2.6 \mathrm{C} / \mathrm{m}^{2}$, maka pada bulan Februari nilainya mencapai 2.9 $\mathrm{C} / \mathrm{m}^{2}$. Hal ini juga diamati ketika dilakukan pengukuran aktivitas ETS (Respiratory Electron Transport System) yang menunjukkan tingkat respirasi mikroba, di mana nilai ETS pada kedalaman $0-300 \mathrm{~m}$ adalah $2.5 \mathrm{~g} \mathrm{C} / \mathrm{m}^{2}$ per hari pada bulan Agustus dan $1.7 \mathrm{~g} \mathrm{C} / \mathrm{m}^{2}$ per hari pada bulan Februari (Vosjan dkk. 1990).

Adapun hasil kajian Zevenboom dan Wetsteyn (1990) menunjukkan bahwa faktor pembatas pertumbuhan pico-plankton $(0,001$ $\mathrm{mm}$ ) pada periode upwelling (Agustus) adalah sinar matahari dan bukan nutrisi. Sebaliknya pada periode downwelling (Februari) pertumbuhannya justru dibatasi oleh ketersediaan nitrat. Pico-plankton sendiri merupakan salah satu komponen penting untuk produktivitas primer di perairan tropis (Arinardi 1999). Khusus untuk picocyanobakteri penghasil pigmen merah phycoeritrin, pico-plankton ini ditemukan dalam konsentrasi yang relatif tinggi (antara $10^{4}-10^{5} \quad \mathrm{sel} / \mathrm{cm}^{3}$ ) di $75 \%$ stasiun pengamatan pada bulan Agustus dan 96\% stasiun pada bulan Februari di Laut Banda (Zevenboom 1990). Lebih lanjut Zevenboom (1990) juga melaporkan bahwa pada bulan Agustus jumlah sel lebih tinggi dibandingkan pada bulan Februari, namun nilai penting relatifnya (sebagai bagian dari total plankton- 
biomassa) justru lebih tinggi pada bulan Februari. Spesies ini mengindikasikan preferensi pada lapisan kolom air yang lebih dalam di mana intensitas cahaya cukup rendah. Hasil ini mendukung pengamatan kajian yang sudah pernah diadakan sebelumnya bahwa picocyanobakteri memiliki nilai penting relatif yang lebih tinggi di perairan yang miskin unsur hara (oligotrof) ketimbang di perairan yang eutrofik seperti di daerah pesisir (Zevenboom 1990).

\section{Zooplankton}

Khusus untuk meso-zooplankton $(200 \mu \mathrm{m}$ $2 \mathrm{~mm}$, organisme dominan adalah kelompok cladocera, copepoda dan larvacea) volume plankton yang lebih besar dari $100 \mathrm{ml} / 1.000 \mathrm{~m}^{3}$ hanya seluas $15 \%$ dari area yang diamati (Arinardi 1999). Lebih lanjut Arinardi (1999) menyatakan bahwa bagian terbesar $(33 \%)$ dari kepadatan volume pada periode downwelling adalah kurang dari $25 \mathrm{ml} / \mathrm{m}^{3}$. Namun dalam masa upwelling terlihat kepadatannya mencapai lebih dari $150 \mathrm{ml} / \mathrm{m}^{3}$ di bagian tenggara Pulau Seram. Sedangkan kepadatan volume terkecil (< $50 \mathrm{ml} / \mathrm{m}^{3}$ ) hanya terlihat sebesar $17 \%$ dan terdapat di bagian tengah Laut Banda. Arinardi sendiri melaporkan hasil penelitian yang cukup berbeda dengan hasil yang diperoleh dalam Ekspedisi Snellius II. Jika pada penelitian Arinardi (1999) diamati kepadatan rata-rata volume zooplankton antara musim barat $(77,60$ $\left.\mathrm{ml} / 1.000 \mathrm{~m}^{3}\right)$ dan musim timur $(87,38 \mathrm{ml} / 1.000$ $\mathrm{m}^{3}$ ) tidak terlalu besar, maka dari hasil Ekspedisi Snellius II dilaporkan bahwa terdapat perbedaan volume hampir tiga kali lipat lebih tinggi pada Musim Timur jika dibandingkan dengan Musim Barat (Baars dkk. 1990). Hal ini kemungkinan besar disebabkan oleh lokasi pengambilan sampel yang lebih ke arah timur dan mencakup Basin Aru pada Ekspedisi Snellius II (Arinardi 1999), di mana perairan utara Laut Arafura ini sudah lama diduga sebagai pusat terjadinya upwelling (Zijlstra dkk. 1990). Baars dkk. (1990) juga menemukan bahwa volume zooplankton semakin bertambah ke arah timur. Hal ini disebabkan karena terjadinya pengayaan dari darat, di samping tentunya karena dampak upwelling.

Dua jenis Copepoda (Calanoides philippinensis dan Rhincalanus nasutus) hanya tertangkap pada bulan Agustus. Kedua jenis ini memang merupakan zooplankton indikator upwelling. Adapun kepadatan C. philippinensis sekitar $27 \mathrm{ind} / \mathrm{m}^{3}$ (Baars dkk. 1990). Jenis yang diperoleh pada kedua musim adalah Euchaeta marina dan Scolecithrix danae. Kelimpahan komunitas zooplankton di Basin Aru dalam musim timur $\left(222 \mathrm{ind} / \mathrm{m}^{3}\right)$ hampir empat kali lipat dibandingkan dalam musim barat $\left(57 \mathrm{ind} / \mathrm{m}^{3}\right)$, dengan produksi sekunder di bagian timur Laut Banda dan Basin Aru sebesar $24 \mathrm{~g} . \mathrm{C} / \mathrm{m}^{2}$ atau mencapai $5 \%$ dari produksi primer (Baars dkk. 1990). Lebih jauh Baars dkk (1990) juga mengemukakan bahwa pada dinamika dan distribusi zooplankton terlihat pengelompokan setempat (patchiness) dan migrasi vertikal yang sangat berperan dalam lapisan $0 \mathrm{~s} / \mathrm{d} 150 \mathrm{~m}$. Pola migrasi harian Copepoda terkait erat dengan tersedianya pakan di dalam air.

Arinardi (1991) mengamati bahwa selama proses upwelling, lima dari delapan jenis yang diamati tidak bermigrasi vertikal tetapi pada saat kandungan klorofil-a rendah (downwelling) sebagian besar Copepoda bergerak naik menjelang senja dan mulai turun ke lapisan dalam pada malam hari. Copepoda indikator seperti $C$. philippinensis selalu berada di lapisan 0-50 m baik pada siang maupun malam hari di perairan dengan kandungan klorofil tinggi, namun di perairan miskin klorofil akan tinggal pada lapisan $250-500 \mathrm{~m}$. Di lain pihak pada saat upwelling zooplankton tidak melakukan migrasi harian atau bahkan cenderung akan bermigrasi ke kolom air lebih dalam dari pada waktu malam (Schalk 1988).

Dalam musim barat, sebaran spasial netfitoplankton dan zooplankton relatif lebih homogen dengan kepadatan di area berbeda (Arinardi 1999). Menariknya, Arinardi (1999) juga menyimpulkan bahwa sebaran spasial dalam musim timur fitoplankton dan zooplankton juga memiliki pola yang berbeda. Hal ini memberikan indikasi bahwa proses upwelling di Laut Banda berlangsung relatif singkat dan bersifat lokal/tidak menyeluruh dalam satuan waktu dan ruang. Dari hasil kajian data Ekspedisi Snellius II, terutama mengenai keberadaan kedua spesies indikator tersebut di atas, proses pengangkatan massa air yang intensif justru terjadi di utara Laut Arafura atau sekitar Basin Aru. Sedangkan massa air pada perairan tenggara Pulau Seram hanya merupakan imbas dari arus (downstream) yang datang dari timur dan di bagian tengah Laut Banda tidak memberikan indikasi sebagai perairan yang subur pada saat upwelling (Arinardi 1999).

\section{Ichtyoplankton}

Menariknya, jika dibandingkan dengan hasil pengamatan Soewito dan Schalk (1990), 
justru tidak terjadi perbedaan yang signifikan pada kelimpahan dan berat rata-rata populasi total ichtyoplankton (larva ikan) jika dibandingkan antara musim timur dan musim barat. Rata-rata dua pertiga larva ikan berada pada kedalaman 0$100 \mathrm{~m}$ di kolom air. Di siang hari larva menunjukkan migrasi vertikal, sampai ke kedalaman 400-500 m, dan terdapat bukti di mana larva mampu menghindari jaring trawl yang dipakai saat pengambilan sampel pada kedalaman 300-500 m. Total 78 marga teridentifikasi sepanjang ekspedisi Snellius II. Kelimpahan larva ikan dari marga Myctophidae dan Gonostomatidae adalah yang tertinggi dari total 61 marga yang diperoleh pada musim timur. Pada musim barat ditemukan 66 marga, di mana Acanthuridae, Myctophidae dan Gonostomatidae merupakan marga yang memiliki kelimpahan tertinggi. Pada musim timur, sekitar $60 \%$ larva berasal dari taksa oseanik dan hanya $30 \%$ yang berasal dari taksa yang sama pada musim barat. Hal ini menunjukkan bahwa hubungan antara larva ikan dan organisme plankton lainnya memang kompleks dan mungkin bervariasi sebagai fungsi dari area yang diteliti (Soewito dan Schalk 1990). Di samping itu juga mungkin disebabkan oleh teknik pengambilan sampel yang tidak mengikuti pola yang lebih sesuai untuk pengambilan sampel, atau justru waktu pengambilan sampel yang tidak tepat (Syahailatua, kom. pribadi). Untuk itu penting dilakukan pemutakhiran data agar diperoleh gambaran yang lebih aktual sesuai kondisi iklim saat ini.

\section{Klorofil-a dan produktivitas perairan}

Indikasi pengaruh musim terhadap kepadatan plankton di perairan Laut Banda juga terlihat dari hasil pengamatan konsentrasi klorofil-a. Analisis matematika dari konsentrasi klorofil-a yang diamati dalam Ekspedisi Snellius II menunjukkan bahwa pada lapisan eufotik teratas (kedalaman $25 \mathrm{~m}$ ) konsentrasinya 5 kali lipat lebih tinggi dalam bulan Agustus 1984 daripada yang diperoleh pada bulan Februari 1985 (Gieskes dkk. 1988). Lebih jauh dilaporkan bahwa pada bulan Februari lapisan klorofil maksimum jeluk (deep chlorophyll maximum layer, DCML) terdeteksi pada kedalaman 40-80 m. Kesamaan pola sebaran pada dua wilayah yang luas di bagian barat dan timur dari Busur Banda merupakan bukti dari pentingnya upwelling dan downwelling yang mempengaruhi fitoplankton pada saat musim timur dan musim barat (Gieskes dkk 1988). Adapun kelompok pigmen fucoxanthin dan variannya (kelompok pigmen yang biasanya terdapat pada diatom) terdeteksi hingga 50\% dari komposisi klorofil-a di zona eufotik pada bulan Agustus. Sedangkan pada bulan Februari kelompok pico- dan nanoplankton yang mengandung 19'hexanoyloxyfucoxanthin (Prymnesiophyceae) dan zeaxanthin (Cyanobakteri) masing-masing terdeteksi hingga $40 \%$ dari total klorofil-a, baik pada lapisan permukaan maupun pada DCML. Namun demikian Gieskes dkk. (1988) mengingatkan bahwa penggunaan profil pigmen untuk menduga komposisi kuantitatif fitolankton alamiah tidak cukup kuat. Hal ini karena perubahan rasio pigmen selain disebabkan oleh adaptasi terhadap cahaya juga dapat disebabkan oleh faktor-faktor ekofisiologis dan fitogeografis.

Di lain pihak, Gieskes dkk. (1990) juga melaporkan bahwa produksi primer mencapai dua kali lipat (1.85 g C/m2.hari) pada bulan Agustus dibandingkan dengan pada bulan Februari (0.91 g C/m2.hari). Hasil ini diperoleh dari pengukuran inkorporasi ${ }^{14} \mathrm{C}$ dalam fitoplankton yang diambil dari bagian timur Laut Banda saat inkubasi in situ, dan dalam inkubator di atas kapal yang dilengkapi dengan filter berwarna biru. Pengukuran produktivitas primer ini juga dilakukan dengan menggunakan metode titrasi Winkler untuk mengetahui kadar oksigen terlarut. Kuosien fotosintesis pada bulan Agustus mencapai 1.05 di dekat lapisan permukaan dan 1.86 pada bagian bawah wilayah eufotik.

Kajian mengenai produktivitas perairan pada musim peralihan baru tersedia setelah tahun 1998, ketika Moore dkk. (2003) melaporkan analisis klorofil-a berdasarkan set data penelitian lapangan yang diambil pada bulan September 1998, dikombinasikan dengan data satelit SeaWiFS Global Area Coverage (GAC) dengan resolusi $9 \mathrm{~km}$. Mereka menyimpulkan bahwa pada permulaan musim peralihan terdapat biomassa fitoplankton yang lebih tinggi di bagian timur Banda jika dibandingkan dengan bagian barat, yang mengindikasikan sisa-sisa dari periode upwelling pada musim timur di bulan-bulan sebelumnya. Data pigmen fitoplankton mengindikasikan komunitas yang didominasi oleh diatom pada bagian timur dan komunitas yang sifatnya lebih oligotrofik (didominasi oleh cyanobakteri) di bagian barat.

Namun secara keseluruhan, rasio tertinggi konsentrasi zeaxanthin (cyanobakteri) terhadap total klorofil-a disinyalir lebih besar (1.3) ketimbang rasio tertinggi konsentrasi fucoxanthin (diatom) terhadap total klorofil-a (0.3) (Moore 
dkk. 2003), sehingga kuat dugaan bahwa cyanobakteri mendominasi Laut Banda pada musim peralihan.

Lebih lanjut, citra satelit mengindikasikan sinyal musiman yang kuat, dengan gradien klorofil a dari bagian timur ke barat, yang secara kebetulan juga dipengaruhi oleh pengaruh fenomena El Niño yang terjadi pada tahun 19971998. Fenomena ini juga turut memperpanjang periode produksi primer di Laut Banda yang menjelaskan tingginya konsentrasi klorofil-a bahkan setelah lewat musim timur pada saat pengambilan sampel. Dalam ekspedisi yang terpisah namun hanya terpaut sebulan (Oktober 1998), Sediadi (2004) mengamati bahwa berdasarkan kelimpahan, keanekaragaman, kemerataan dan distribusinya, dua jenis cyanobakteri yakni Trichodesmium eryhtraeum dan Trichodesmium thiebautii mendominasi pada musim peralihan. Kedua kajian yang berbeda tersebut terlihat konsisten dengan penelitianpenelitian sebelumnya bahwa cyanobakteri merupakan kelompok fitoplankton indikator perairan yang oligotrofik, yang dalam konteks Laut Banda diakibatkan oleh mulai berlangsungnya proses penurunan massa air pada musim peralihan.

\section{Kajian tahun 2000-2013}

Ekspedisi Laut Banda yang dilakukan oleh Pusat Penelitian Laut Dalam (PPLD) LIPI pada bulan November 2013 menariknya menunjukkan hasil yang cukup berbeda dari kedua hasil penelitian yang baru dibahas terdahulu dan agak berlawanan dengan hipotesa yang sudah diajukan pada kajian-kajian sebelumnya. Ekspedisi ini dilakukan terutama pada wilayah bagian atas Laut Banda. Wilayah ini mencakup perairan lepas yang berada di bagian tenggara pulau Buru, dan bagian selatan pulau Ambon hingga Pulau Seram, pada posisi geografis 3.5$5^{\circ}$ LS dan $127-130^{\circ}$ BT. Tujuannya adalah untuk memberikan informasi terkini mengenai kondisi hidrologi, oseanografi biologi dan larva ikan (Salamena dkk., 2013).

\section{Fitoplankton}

Diatom ditemukan sebagai kelompok yang mendominasi struktur komunitas fitoplankton dengan persentase kehadiran mencakup 75\% dari total genus yang diamati. Kelimpahannya berkisar antara $7,7 \times 10^{4}-2,69 \times 10^{5} \mathrm{sel} / \mathrm{m}^{3}$. Adapun genus yang teridentifikasi tidak terlalu jauh berbeda dengan yang dilaporkan oleh
Adnan (1990) dan Arinardi dkk. (1997) pada musim barat yakni Chaetoceros, Bacteriastrum, Thalassiotrix, di samping Rhizosolenia, Nitzschia, Thalassionema, Thalassiosira, Cylindrotheca dari kelompok Diatom, Ceratium dan Pyrocytis dari kelompok Dinoflagelata dan Trichodesmium dari kelompok Cyanobacteria.

\section{Zooplankton}

Kelimpahan tertinggi zooplankton (225 ind $/ \mathrm{m}^{3}$ ) diamati pada bagian tenggara Pulau Buru, dan kelimpahan terendah $\left(1.730 \mathrm{ind} / \mathrm{m}^{3}\right)$ tercatat di bagian tenggara Pulau Seram. Copepoda merupakan kelompok yang mendominasi $(60 \%)$ struktur komunitas zooplankton di bagian tenggara Pulau Buru. Hasil ini cukup berlawanan dalam beberapa hal berikut. Pertama, cyanobakteri sebagai indikator perairan yang oligotrof tidak mendominasi struktur komunitas fitoplankton. Kedua, copepoda justru merupakan zooplankton indikator upwelling yang secara teori tidak akan mendominasi perairan yang dipengaruhi downwelling. Ketiga, dari kelimpahan fitoplankton dan zooplankton secara total justru ditemui yang terendah pada stasiun-stasiun penelitian yang lebih ke timur, yang notabene lebih dekat dengan pulau-pulau kecil di bagian tenggara Pulau Seram. Padahal semestinya pengaruh dari daratan akan memberikan pengayaan di perairan yang lebih intensif ketimbang yang lebih dekat ke arah laut lepas.

Ada beberapa hipotesa yang mungkin dapat menjelaskan terjadinya beberapa perbedaan ini dengan kajian-kajian terdahulu.Yang pertama, pada bulan November 2013 mungkin saja masih terjadi pengayaan di lapisan permukaan akibat pengadukan massa air sehingga produksi primer masih berlanjut. Hal ini terlihat dari profil oksigen terlarut pada lapisan permukaan yang rata-rata lebih dari $5 \mathrm{ppm}$ dan konsentrasi nitrat yang berada pada kisaran lebih dari 0,008-0,01 ppm (Salamena dkk. 2013). Kadar fosfat di permukaan berkisar antara 0,001 sampai dengan 0,01 ppm, dan hal ini mungkin diakibatkan oleh penggunaannya oleh fitoplankton dalam proses metabolismenya. Yang kedua, tahun 2013 ditandai dengan pergeseran musim yang sifatnya temporal, di mana jika sebelumnya musim penghujan dimulai pada bulan Mei, maka pada tahun tersebut bergeser hingga bulan Juni. Pergeseran seperti ini dengan demikian mengakibatkan terjadinya pergeseran musim timur sampai melebihi bulan Agustus. 
Yang ketiga, perbedaan ini mungkin disebabkan karena luasan area penelitian yang terlalu sempit, sehingga area pengambilan sampel tidak cukup representatif untuk menggambarkan keragaan Laut Banda secara umum. Yang keempat, mungkin saja pada lokasi pengambilan sampel di Laut Banda ini kelimpahan plankton justru tidak dipengaruhi oleh musim, sehingga dapat ditemui di sepanjang tahun. Hipotesa yang terakhir ini justru akan lebih mampu menjelaskan salah satu faktor yang menyebabkan mengapa musim tidak berpengaruh terhadap kelimpahan ichthyoplankton di Laut Banda. Namun demikian, semua hipotesis ini patut untuk diuji pada ekspedisi kelautan yang harus dilakukan pada tahun-tahun berikutnya.

\section{Ichthyoplankton}

Taufik dkk. (2005) dalam kajian awal mengenai lokasi pemijahan ikan pelagis yang dominan di perairan Teluk Tomini dan Laut Banda menemukan larva dari 25 marga ikan pada perairan yang disebutkan terakhir. Mereka lebih lanjut menemukan bahwa larva ikan yang mendominasi di Laut Banda adalah dari marga Clupeidae, Scombridae dan Ambassidae. Namun tidak dapat diaksesnya artikel ini secara lengkap terkait dengan waktu pengambilan sampel dan metodologi yang dipakai, seperti luas daerah pengamatan, proses pengambilan sampel dan alat tangkap yang digunakan, mengakibatkan tidak dapat dilakukannya analisa jika seandainya terjadi perbedaan dengan hasil yang akan diperoleh dalam penelitian yang akan dilakukan di kemudian hari.

\section{Implikasi bagi pembangunan kelautan dan perikanan}

Teori yang diterima dalam komunitas masyarakat ilmiah, khususnya yang bergerak dalam oseanografi biologi selama ini adalah bahwa dengan terjadinya pengangkatan massa air di suatu perairan, otomatis akan menyebabkan kelimpahan fitoplankton yang tinggi, yang merupakan produsen primer. Perairan yang subur pada gilirannya akan menjadi daerah yang potensial untuk pemijahan ikan dewasa dan penetasan larva ikan. Padahal, seperti yang sudah diamati oleh Soewito dan Schalk (1990) hubungan antara ichthyoplankton dan organisme planktonik lainnya justru lebih kompleks dan mungkin bervariasi dengan wilayah yang diamati. Mekanisme biologis yang mendasari hubungan linier antara produktivitas perikanan pelagis kecil pada wilayah pesisir dan periode upwelling sifatnya spesifik, baik dari segi spesies maupun wilayah (Syahailatua dkk, 2011).

Khusus mengenai ikan tuna sirip kuning (yellow fin tuna, YFT), informasi yang disajikan di atas belumlah memadai sebagai data ilmiah yang memberikan bukti-bukti yang cukup bahwa Laut Banda memang merupakan lokasi pemijahannya (Syahailatua, kom. pribadi). Hal ini diindikasikan dalam laporan penelitian Itano (2000) yang menyimpulkan bahwa proporsi ikan YFT betina dewasa dalam kondisi memijah di Maluku justru lebih rendah dibandingkan dengan sampel yang ditangkap di wilayah perairan Filipina, dengan sekitar $50 \%$ ikan sampel berada pada kondisi memijah atau siap memijah per bulan.

Penelusuran informasi secara non formal yang dilakukan dengan nelayan tuna belum lama ini mengungkapkan ditemukannya anakan ikan tuna saat penangkapan di luar mulut Teluk Ambon bagian Luar, yang merupakan bagian dari Laut Banda. Namun belum ada kajian yang memberikan bukti bahwa anakan yang tertangkap itu berasal dari ichthyoplankton hasil pemijahan lokal. Sebab walaupun terbatas, kemampuan renang ichthyoplankton memungkinkan kelompok ini untuk beruaya dari Samudera Pasifik sampai ke Laut Banda.

Kajian mengenai distribusi larva tuna di sekeliling kepulauan Hawaii mengungkapkan kelimpahan larva tuna yang tinggi di dekat pesisir $\left(441 / 1.000 \mathrm{~m}^{3}\right)$ (Miller 1979). Ini merupakan indikasi bahwa mungkin saja di perairan Maluku, ichthyoplankton dari marga Scambridae lebih banyak berada di wilayah pesisir, dan bukan di pertengahan Laut Banda, sehingga sebenarnya pelarangan penangkapan YFT pada bulan Oktober-Desember mungkin tidak terlalu efektif dalam menjamin ketersediaan stok YFT. Hal ini karena YFT cenderung memijah pada saat suhu permukaan laut (Sea Surface Temperature, SST) berkisar antara $25-29^{\circ} \mathrm{C}$, sehingga kemungkinan besar pemijahan justru akan terjadi di antara bulan Mei hingga Agustus sepanjang tahunnya (Syahailatua, kom. pribadi).

Lebih lanjut Miller (1979) berpendapat jika reaksi larva tuna terhadap faktor-faktor lingkungan di pesisir tidak jauh berbeda dengan di laut lepas, maka sebenarnya hubungan antara kelimpahan larva tuna dengan YFT dewasa dapat dipelajari dengan menganalisa perilaku larva tuna yang berada di pesisir. Ditemukannya larva tuna di pesisir Kepulauan Hawai 
merupakan indikasi bahwa kajian mengenai larva tuna dapat dilakukan di pesisir, sehingga mampu mereduksi aktivitas pengambilan sampel di laut lepas dengan tetap memperoleh data kelimpahan yang hampir sama tingginya seperti yang dilaporkan pada tahun 1960-an oleh Strasburg (Miller 1979). Untuk itu diperlukan juga penelitian yang lebih mendalam mengenai keberadaan larva ikan pada wilayah perairan pesisir pulau-pulau yang berada di Laut Banda, yang kemudian akan dibandingkan dengan keberadaannya di tengah perairan tersebut, sehingga diperoleh gambaran yang sifatnya lebih integral.

\section{Kesimpulan}

Secara substantif tampak jelas bahwa masih banyak sebenarnya yang belum diketahui mengenai Laut Banda untuk memberikan gambaran akan karakteristik oseanografi biologi yang cukup representatif sesuai kondisi aktual perairan tersebut. Data mengenai produktivitas primer dan mikroorganisme yang berperan penting di dalamnya belumlah cukup untuk melakukan hal itu. Untuk itu diperlukan kajian yang sifatnya reguler (bulanan), atau setidaknya mewakili keempat musim, terhadap parameter yang mempengaruhi karakteristik oseanografi biologi di perairan ini. Di samping itu perubahan iklim akan sangat mempengaruhi dinamika mikroorganisme yang menjadi produsen primer dan produsen sekunder di perairan.

Dari segi teknis operasional, diperlukan kerja sama yang solid di antara instansi terkait di Provinsi Maluku untuk memutakhirkan data sehingga analisa yang dilakukan sesuai dengan kondisi aktual. Data yang komprehensif seperti pada Ekspedisi Snellius II diambil hampir 30 tahun yang lalu dan karenanya harus kembali diperbarui, karena telah terjadi begitu banyak perubahan dalam jangka waktu tersebut. Lebih khusus menyangkut YFT, data komprehensif yang dikeluarkan oleh Itano (2000) juga memerlukan verifikasi ulang setelah 15 tahun. Hasil Ekspedisi Laut Banda yang telah dilakukan oleh PPLD LIPI pada tahun 2013 tidaklah cukup untuk memberikan gambaran yang komprehensif mengenai kondisi oseanografi biologi Laut Banda yang terkini, karena dilakukan dalam waktu yang cukup singkat (10 hari layar) sehingga tidak dapat mencakup seluruh wilayah Laut Banda yang merupakan sebagian WPP-RI 714.

Berkaca pada informasi dan analisa yang disampaikan di atas, dalam rangka memperkuat kebijakan pembangunan kelautan dan perikanan berbasis Laut Banda, terdapat kebutuhan yang mendesak sifatnya untuk menginisiasi pembentukan platform pengkajian biologi perikanan beserta kondisi oseanografi pendukungnya yang terintegrasi, yang tidak hanya menyangkut wilayah laut lepas tapi juga pesisir pulau-pulau yang terdapat di laut Banda. Pusat Penelitian Laut Dalam sendiri sebagai otoritas saintifik bidang kelautan di Kawasan Timur Indonesia dapat menjadi fasilitator untuk membentuk platform ini dan memastikan terlaksananya kajian-kajian ilmiah yang akan memberikan luaran yang dapat diaplikasikan dalam pengambilan kebijakan mengenai pengelolaan hasil kelautan dan perikanan berbasis Laut Banda di masa-masa mendatang.

\section{Ucapan terimakasih}

Penulis mengucapkan terima kasih kepada Dr. Augy Syahailatua atas masukan yang berharga berupa rujukan pustaka dan diskusi dari segi biologi perikanan yang telah memperkaya tulisan ini. Tulisan ini merupakan kontribusi no. 0008 dari Laboratorium Mikrobiologi dan Bioteknologi Laut, Pusat Penelitian Laut Dalam LIPI.

\section{Daftar Pustaka}

Adnan, Q. 1990. Monsoonal differences in netphytoplankton in the Arafura Sea. Netherlands Journal of Sea Research 25 (4): 523-526.

Arinardi, O.H. 1999. Sebaran Volume Plankton di Laut Banda, Sebelum dan Selama Proses Upwelling, dalam Suyarso (Ed.), Atlas Oseanologi Laut Banda, P3O LIPI Jakarta, 53-62.

Arinardi, O.H., Sutomo, A.B., Yusuf, S.A., Trimaningsih, E., Asnaryanti., Riyono, S.H. 1997. Kisaran Kelimpahan dan komposisi plankton predominan di perairan Kawasan Timur Indonesia, P3O LIPI:140 pp.

Baars, M.A., Sutomo, A.B., Oosterhuis, S.S., Arinardi, O.H. 1990. Zooplankton abundance in the eastern Banda Sea and northern Arafura Sea during and after the upwelling season, August 1984-February 1985. Netherlands Journal of Sea Research 25 (4): 527-543.

Besewni., Effendi, D.S., Agustineke, R., Nugroho., Nugroho, G.D., Susilo, A.W., Suhadi (Eds). 2011. Peta keragaan perikanan tangkap wilayah pengelolaan 
perikanan. Republik Indonesia (WPP-RI). DirJen Perikanan Tangkap KKP RI, cetakan III, 57 halaman.

Birowo, S. 1984. Ekspedisi ilmiah kelautan Snellius II, Indonesia-Belanda (Juli 1984Juli 1985). Berita Ilmu Pengetahuan dan Teknologi -LIPI 28: 23-42.

Gieskes, W.W.C., Kraay, G.W., Nontji, A., Setiapermana, D., Sutomo. 1988. Monsoonal Alternation Of A Mixed And A Layered Structure In The Phytoplankton Of The Euphotic Zone Of The Banda Sea (Indonesia): A Mathematical Analysis Of Algal Pigment Fingerprints. Netherlands Journal of Sea Research 22 (2): 123-137.

Gieskes, W.W.C., Kraay, G.W., Nontji, A., Setiapermana, D., Sutomo. 1990. Monsoonal Differences In Primary Production In The Eastern Banda Sea (Indonesia). Netherlands Journal of Sea Research 25 (4): 473-483.

llahude, A.G. 1999. Sebaran parameter hidrologi di Laut Banda Timur.dalam Suyarso (ed.). Atlas Oseanologi Laut Banda. P3O LIPI Jakarta, h. 15-53.

Itano, D.G. 2000. The reproductive biology of yellowfin tuna (Thunnus albacares) in Hawaiian waters and the Western Tropical Pacific Ocean: Project Summary, SOEST 00-01, JIMAR Contribution 00-328. Diakses tanggal 28 April 2015. http://www.soest.hawaii.edu/PFRP/biology/ itano.html.

Moore II, T.S., Marra, J., Alkatiri, A. 2003. Response of the Banda Sea to the southeast monsoon. Marine Ecology Progress Series 261: 41-49.

Schalk, P.H. 1988. Respiratory electron transport system (ETS) activities in zooplankton and micronekton of the Indo-Pacific Region. Doctor Theses, University van Amsterdam, 49-60.

Sediadi, A. 2004. Dominasi cyanobacteria pada musim peralihan di perairan Laut Banda dan sekitarnya. Makara Sains 8 (1): 1-14.

Soewito, PH Schalk. 1990. Spatial and seasonal patterns in fish larvae distribution in the Banda Sea (Indonesia). Netherlands Journal of Sea Research 25 (4): 591-600.

Syahailatua, A., Taylor, M.D., Suthers, I.M. 2011. Growth variability and stable isotope composition of two larval carangid fishes in the East Australian Current: The role of upwelling in the separation zone. Deep Sea Research II 58: 691-698.

Taufik, M., Suwarso., Nuriyanto. 2005. Distribusi kelimpahan ichthyoplanton di Teluk Banda, Jurnal Penelitian Perikanan Indonesia 11 (6): 73-81.

Miller, J.M. 1979. Nearshore abundance of tuna (Pisces: Scombridae) larvae at the Hawaiian Islands. Bulletin of Marine Science 29 (11):19-26.

Salamena, G., Sapulette, D., Wouthuysen, S. 2013. Ekspedisi Laut Banda. Laporan Penelitian. Pusat Penelitian Laut Dalam LIPI, Ambon. 30 hal.

Suyarso. 1999. Lingkungan Fisik Kawasan Laut Banda dalam Suyarso (ed). Atlas Oseanologi di Indonesia. hh. 1-5.

Vosjan, J.H., Nieuwland, G., Ruyitno. 1990. Monsoonal differences in microbial biomass, respiratory activity and bacterial numbers in the Banda Sea. Netherlands Journal of Sea Research 25(4): 501-511.

Wyrtki, K. 1958. The water exchange between the Pacific and the Indian Ocean in relation to upwelling processes. Proc. 9th Pac. Sci Congr. 16:61-66.

Wyrtki, K. 1961. Physical Oceanography of the South-East Asian Waters, Naga Report 2: 1-195.

Zevenboom, W., Wetsteyn, F.J. 1990. Growth limitation and growth rates of (pico)phytoplankton in the Banda Sea during two different seasons. Netherlands Journal of Sea Research 25 (4): 465-472.

Zevenboom, W. 1990. Picocyanobacteria in the Banda Sea during two different monsoons. Netherlands Journal of Sea Research 25 (4): 513-521.

Zijlstra, J.J., Baars, M.A., Tijssen, S.B., Wetsteyn, F.J., llahude, A.G., Hadikusumah. 1990. Monsoonal effects on the hydrography of the upper waters $(<300$ $\mathrm{m})$ of the eastern Banda Sea and northern Arafura Sea, with special reference to vertical transport process. Netherlands Journal of Sea Research 25(4): 431-447. 